\title{
Environmental control of the annual erect phase of Nemalion helminthoides (Rhodophyta) in the field
}

\author{
LORENA S. PATO ${ }^{1}$, BREZO MARTÍNEZ ${ }^{2}$ and JOSÉ M. RICO ${ }^{3}$ \\ ${ }^{1}$ Área de Ecología, Dpto. Biología de Organismos y Sistemas, Universidad de Oviedo, C/ Catedrático Rodrigo Uría s/n, \\ E-33071 Oviedo, Spain. \\ 2 Área de Biodiversidad y Conservación, Escuela Superior de Ciencias Experimentales y Tecnología, Universidad Rey \\ Juan Carlos, C/ Tulipán s/n, E-28933 Móstoles, Madrid, Spain. \\ ${ }^{3}$ Área de Ecología, Dpto. Biología de Organismos y Sistemas, Universidad de Oviedo, C/ Catedrático Rodrigo Uría s/n, \\ E-33071 Oviedo, Spain. E-mail jmrico@ uniovi.es
}

\begin{abstract}
SUMMARY: In temperate areas, lack of nutrients during summer, particularly $\mathrm{N}$, is the main limiting factor of macroalgal growth. However, Nemalion helminthoides (Velley) Batters in northern Spain is conspicuous in the field during this time (from mid-May to late-July). Therefore, we assumed that its nutrient requirements are low enough to be sustained by transient nutrient inputs and we hypothesized that the physiological condition of the thalli was transiently improved when nutrient pulses occurred. A range of proxies for physiological condition (internal N, C, proteins and phycobilins), growth and phenological status of $N$. helminthoides were measured over time and related to temporal variations in nutrient availability, irradiance, temperature and daylength. Data were analyzed using a multivariate approach (redundancy analysis). Transient nutrient inputs were mainly due to freshwater runoff and wind-driven upwelling events; however, these pulses did not lead to any short-term improvement in the physiological condition of the algae because in such dominant nutrient limiting conditions plants divert transient available resources directly to growth and reproduction. Probably because of the strong endogenous nature of the $N$. helminthoides life-history, only daylength and temperature were found to be major environmental factors: increasing daylength was associated with growth, sexual maturation, fertilization and the increment of internal $\mathrm{N}$ and $\mathrm{C}$, the amount of proteins and phycobilins. Decreasing daylength together with increasing temperature were correlated with spore release and senescence. This research suggests that $N$. helminthoides requires a high light dose to sustain growth and reproduction, and therefore it must grow and reproduce in summer even though it has to overcome nutrient deprivation during this period.
\end{abstract}

Keywords: carbon, daylength, multivariate, Nemalion helminthoides, nitrogen, phenology, phycobilins, protein, RDA, temperature.

RESUMEN: Control AMBIENTAL DE LA FASE MACROSCÓPICA DE NEMALION HELMINTHOIDES (RHODOPHYTA) EN EL CAMPO. En las costas templadas la falta de nutrientes durante el verano, y en particular la falta de N, es la causa principal de la limitación del crecimiento de las algas. Sin embargo en la costa N de España Nemalion helminthoides (Velley) Batters aparece precisamente durante esta época del año, desde mediados de mayo a finales de julio. Por ello se asume que sus requerimientos de nutrientes son lo suficientemente bajos como para aprovechar pulsos ocasionales, y se plantea la hipótesis de que la condición fisiológica del talo mejora durante la ocurrencia de estos pulsos. Para comprobar esta hipótesis se midieron indicadores de la condición fisiológica tales como el contenido interno de N, C, proteínas y ficobilinas, además del crecimiento y del estado fenológico a lo largo del periodo de crecimiento estival, que se han relacionado con variaciones temporales en disponibilidad de nutrientes, irradiancia, temperatura y fotoperiodo. Los datos se analizaron utilizando una aproximación multivariante (Análisis de Redundancia). Los pulsos ocasionales se debieron fundamentalmente a aportes fluviales y fenómenos de afloramiento costero, pero éstos no produjeron ninguna mejora a corto plazo en la condición fisiológica porque la limitación experimentada por las plantas hizo que éstas dedicaran los recursos disponibles directamente a crecimiento y reproducción. Probablemente, dado el estricto control endógeno del ciclo de vida de $N$. helminthoides, solamente el fotoperiodo y la temperatura aparecen como factores ambientales importantes: el aumento del fotoperiodo se asocia con el crecimiento, la maduración de las estructuras reproductoras, la fecundación y los aumentos de los contenidos celulares de N, C, proteínas y ficobilinas. El descenso del fotoperiodo en julio, unido al aumento de temperatura, se correlacionó con la liberación de las esporas y la senescencia. Estos resultados sugieren que la especie necesita altos niveles de irradiancia para mantener el crecimiento y la reproducción, lo que obliga a las plantas 
a crecer y reproducirse en la época estival, aunque teniendo que superar al mismo tiempo la situación de disminución de disponibilidad de nutrientes.

Palabras clave: carbono, fotoperiodo, análisis multivariante, Nemalion helminthoides, nitrógeno, fenología, ficobilinas, proteina, RDA, temperatura.

\section{INTRODUCTION}

Macroalgae are the most important primary producers in temperate coastal areas (Valiela, 1995). In these systems, long days during summer are correlated with increasing temperature, light-dose and generally calm sea conditions. This environmental setting primarily enhances macroalgal growth, except when this is limited by low nutrient supply, particularly $\mathrm{N}$, as frequently reported (Fujita et al., 1989; Duarte, 1992; Lüning, 1993; Pedersen and Borum, 1996; Reed et al., 1996; Kinlan et al., 2003; Hwang et al., 2004).

Despite nutrient limitation during summer, a few marine algae (or at least the macroscopic phases of their life cycle) appear and develop in the field mainly during this period. This is the case of $N$. helminthoides, a red seaweed with summer-annual development that belongs to the order Nemaliales (Dixon and Irvine, 1977). This species has an heteromorphic life-history: the erect phase is conspicuous during late spring-summer, whereas during winter, only the filamentous tetrasporophyte perennates can be seen (Martin, 1969). Therefore, the common strategy adopted by perennial seaweeds of storing nutrient pools (mainly proteins and phycobilins in red seaweeds) in winter in order to overcome the summer nutrient limitation is not possible (Wheeler and Björnsäter, 1992; Rico and Fernández, 1996; Pedersen and Borum, 1996; Pueschel and Korb, 2001; Martínez and Rico, 2002). Consequently, summer-annual seaweeds need to be able to survive with the small amounts of nutrients available. These nutrients are mainly provided in the form of transient pulses. However, the physiological response may depend greatly on the nutrient storage capability of the species at short time scales (Vergara et al., 1995; McGlathery, 1996; Pedersen and Borum, 1996; Costanzo et al., 2000; Nielsen, 2003; Bracken, 2004; Clavier et al., 2005; Lartigue and Sherman, 2005).

The lack of winter nutrient pools in $N$. helminthoides makes it especially suitable for an investigation of how macroalgae may overcome summer nutrient limitations and benefit from nutrient pulses. Our specific hypothesis was that there is a positive relationship between the occurrence of transient nutrient inputs and a shortterm improvement in the physiological condition of $N$. helminthoides in the field. There are different sorts of nutrient pulses, in particular we focussed on upwelling events, terrestrial freshwater inputs and rainfall. Intermittent upwelling episodes in this geographical area have been reported before (Botas et al., 1990; Arrontes, 1993; Rico and Fernández, 1996; González et al., 2003; O'Riordan et al., 2004), and therefore we carried out an intensive survey of seawater nutrient levels. We selected a locality where other natural sources of nutrient inputs also occurred, in particular the presence of a small freshwater stream.

The development of the erect phase of $N$. helminthoides from isolates from $\mathrm{W}$ Ireland was triggered by days being longer than $14 \mathrm{~h}$ at less than $17^{\circ} \mathrm{C}$ (Cunningham and Guiry, 1989). On the coast of $\mathrm{N}$ Spain $\left(43^{\circ} 34^{\prime} \mathrm{N}\right)$ these conditions are found around mid-May when $N$. helminthoides starts to colonize the upper faces of intertidal rocky boulders, at the lowest nutrient levels of the year (Rico and Fernández, 1996; Martínez and Rico, 2002; Sánchez and Fernández, 2006). Other seaweeds also follow this kind of cycle, such as many Porphyra species (Lubchenco and Cubit, 1980, Hernández et al., 1993; Pedersen et al., 2004), the sea palm Postelsia palmaeformis (Blanchette, 1996), and the brown seaweed Desmarestia ligulata (Dayton et al., 1992, Edwards, 2000). Traditionally, research on annuals has focused on determining what environmental factors cause life-stage changes, frequently prompted by very precise combinations of daylength and temperature, e.g. Bonnemaisonia hamifera (Breeman and Guiry, 1989), and Asparagopsis armata (Guiry and Dawes, 1992). These two factors were taken into account and the net growth oscillations and reproductive (phenological) status of $N$. helminthoides were addressed during the field survey.

Since many variables were considered, a multivariate approach was adopted. The redundancy analysis used here meets a mid point between descriptive and empirical research (ter Braak, 1999). This allowed us to test the particular hypothesis concerning the physiological response to transient nutrient pulses, while investigating the general phenological and physiological patterns potentially related to the $N$. helminthoides endogenous cycle. To our knowledge, this is the first attempt to perform such comprehensive monitoring of a summer-апnиal macroalgae in response to several sources of nutrient pulses in the field.

\section{MATERIALS AND METHODS}

\section{Sampling area}

The location selected for the study was La Concha

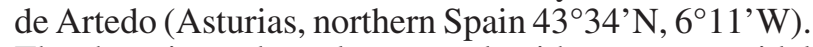
The shore is moderately exposed, with an average tidal range of $2.2 \mathrm{~m}$. Nemalion helminthoides was distributed in a small area (about $300 \mathrm{~m}$ ) located at the eastern border of a broad rocky platform. This area can be described as a transitional region between the rocky platform and the beach and is surrounded by a freshwater 


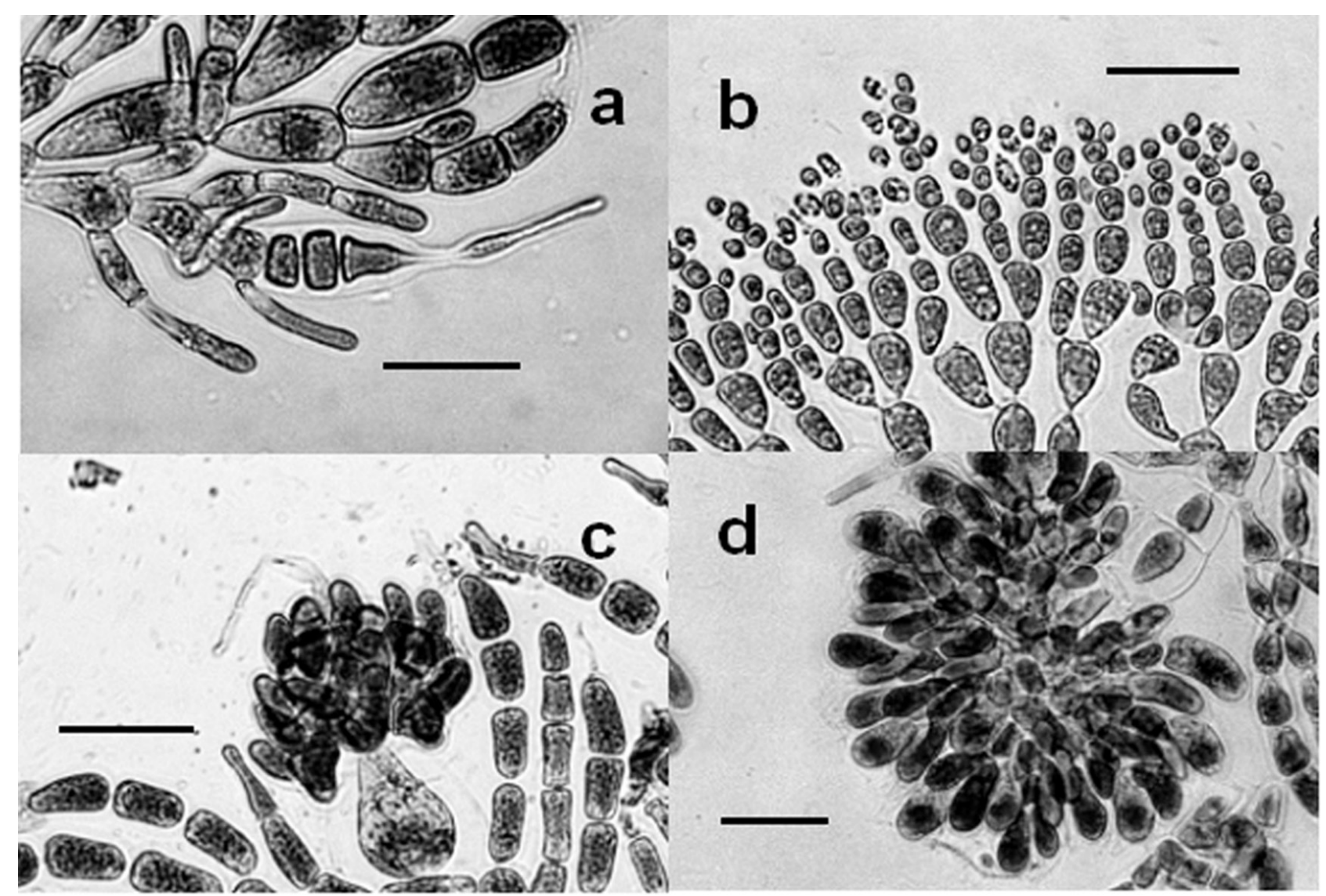

FIG. 1. - Phenological classes. a) Individual showing female gamete; b) Individual showing male gametes; c) Individual showing fertilization in female gamete; d) Individual releasing spores. Scale bar equals $25 \mu \mathrm{m}$.

stream from the eastern side. $N$. helminthoides usually colonizes the upper face of the biggest boulders on the upper part of the Chthamalus belt. Samples were collected weekly, from the first presence of young erect plants in mid-May 2003 until their disappearance in late July 2003.

\section{Percentage cover}

$N$. helminthoides fronds are cylindrical and most growth is longitudinal. Populations spread over the rocky surfaces forming a flat layer, and therefore we selected cover as a proxy for growth. Fourteen $10 \times 10$ $\mathrm{cm}$ quadrats were randomly distributed within the sampling area. In order to allow repeated sampling, we made permanent marks on the rock surfaces coinciding with the two opposite corners of the quadrat frame. Four quadrats were located within the first $100 \mathrm{~m}$ fringe from the freshwater stream (site 1), five within the 100-200 $\mathrm{m}$ fringe (site 2), and five within the 200-300 m fringe (site 3). The mean distance between quadrats was around $10-30 \mathrm{~m}$. The percentage cover was estimated weekly by the point-intercept method using a square plastic frame that held a $1 \times 1 \mathrm{~cm}$ mesh (121 intercept points where the presence or absence of $N$. helminthoides was noted).

\section{Phenology}

Once a week, ten plants were randomly collected from the sampling area. The collection site was chosen by randomly selecting an area adjacent to 2 of the marked quadrats, and collecting 5 plants at each one. Samples were fixed in $4 \%$ formalin-seawater and kept in complete darkness until examination. For microscopy observation of reproductive structures 5 pieces (2-3 $\mathrm{mm}$ ) of each plant were excised, stained with anilineblue and squashed on a microscope slide. Each plant was assigned to a phenological class using the following criteria: forming male or female gametes (Fig. 1a, b), showing fertilization of the female gametes (Fig. 1c), or releasing spores (Fig. 1d).

Biochemical analysis. Once a week, eight plants were collected at random from the sampling area. They were transported to the laboratory inside an isotherm bag $\left(<4^{\circ} \mathrm{C}\right.$, in darkness) and divided into samples of fresh tissue. Samples were blotted dry, weighed and preserved at $-20^{\circ} \mathrm{C}$ until the analysis of internal biochemical contents. Four samples from different individuals were used each week to determine internal $\mathrm{C}$ and $\mathrm{N}$ contents using a CHN elemental auto-analyzer (Perkin Elmer Analytical Instruments, Shelton, CT, USA). From each of the 8 plants collected two different samples were 
used to determine total protein and phycobilins. Samples were ground in a mortar and pestle with liquid N. Proteins were extracted over $24 \mathrm{~h}$ in darkness with SDS (1\%) and assayed following Lowry's protocol (1951) using BSA (Merck, Frankfurter, Darmstadt, Germany) as standard. Phycobilins (phycoerythrin and phycocyanin) were extracted with $0.05 \mathrm{M}$ phosphate buffer and quantified using Beer and Eshel (1985) trichromatic equations. To express the biochemical contents as a percentage of dry weight (DW), a sample from each plant was dried $\left(60^{\circ} \mathrm{C}\right.$ until constant weight) to determine the fresh:dry weight ratio.

\section{Environmental variables}

Seawater samples for nutrient analysis were taken at least weekly. Increases in seawater nutrients associated with wind-driven upwelling events were detected using daily meteorological forecasting and additional nutrient samples taken under wind-favourable conditions. Triplicate seawater samples were taken at three different sites within the sampling area. Site 1 was next to the freshwater runoff on the eastern side of the sampling area, site 3 was on the opposite side, and site 2 was in between. Samples were filtered in situ $(0.7 \mu \mathrm{m} \mathrm{GF} / F$ filters, Whatman International Ltd., $\mathrm{UK})$, and transported to the laboratory $\left(<4^{\circ} \mathrm{C}\right.$, in darkness), where they were kept at $-20^{\circ} \mathrm{C}$ until analysis. Nitrate + nitrite $\left(\mathrm{NO}_{3}{ }^{-}+\mathrm{NO}_{2}{ }^{-}\right)$, ammonium $\left(\mathrm{NH}_{4}{ }^{+}\right)$and orthophosphate $\left(\mathrm{HPO}_{4}{ }^{3-}\right)$, were determined using an automated wet chemistry analyzer (SKALAR San $^{++}$ System, Breda, The Netherlands), following standard protocols (Grasshoff et al., 1983).

Seawater temperature was measured with a continuous data logger (ONSET Computer Corp., Pocasset, MA, USA). The thermometer was fixed in the low intertidal and only data collected during high tides were taken into account. Daily series of direction and intensity of winds were kindly provided by Puertos del Estado from a meteorological station located close to the sampling area (Cabo Peñas, $43^{\circ} 39^{\prime} \mathrm{N}, 05^{\circ} 50^{\prime} \mathrm{W}$, alt: $100 \mathrm{~m}$ ). These data were used to calculate an Upwelling Index (Bakum, 1973). Daily precipitation data were taken from the same station. Integrated global irradiance reaching the surface $\left(\mathrm{Kj} \mathrm{m}^{-2} \mathrm{~d}^{-1}\right)$ was provided by the Instituto $\mathrm{Na}$ cional de Meteorología from the meteorological station at La Coruña $\left(43^{\circ} 22^{\prime} \mathrm{N}, 08^{\circ} 25^{\prime} \mathrm{W}\right)$. Daylength variations were calculated as in Kirk (1983).

\section{Statistical analysis}

We used a multivariate approach (ter Braak, 1999) in order to test our particular hypothesis (physiological response to transient nutrient inputs) and to determine general variation patterns between variables measured in the plants and in the environment (endogenous cycle). For this purpose, we used a redundancy analysis (RDA), which is a canonical ordination technique in which a response data set is constrained to a given group of environmental variables. Axes resulting from the ordination must therefore be linear combinations of the provided explanatory variables. In this approach the relative variation among samples and the relationships between response and environmental variables can be visualized in a single bi-dimensional plot (Palmer, 1993). A preliminary Principal Component Analysis (PCA), in which the set of environmental variables is not considered, was performed to evaluate the suitability of a multivariate approach. The PCA and RDA results were compared to determine whether any important environmental variables had been overlooked. Furthermore, the RDA allowed us to use iterative procedures to test the significance of the ordination axis. The significance of the second axis was tested considering the first axis sample scores as covariables (Lepš and Šmilauer, 2003). The conditional contribution of each environmental variable used in the analysis was assessed with a forward selection procedure. When the effect of a variable was judged to be non-random $(p<0.05)$ it was included in the reduced model. The amount of variation explained by each of these selected variables was quantified in partial analyses in which each variable was considered as the only explanatory factor and the others were added as covariables (Lepš and Šmilauer, 2003). We used linear models like PCA and RDA because the response models of physiological and life cycle variables in the field are usually linear. For the environmental variables that showed an oscillatory pattern of variation a weighted mean value considering the five previous days was used in the analysis.

\section{RESULTS}

\section{Variations in cover}

The mean percentage cover showed maximum values between 7 and 27 June (Fig. 2a). Plants located within the $200 \mathrm{~m}$ fringe closest to the freshwater stream (sites 1 and 2) showed a higher percentage of cover than plants located within the last $100 \mathrm{~m}$ fringe away from the freshwater (site 3), particularly during the periods of maximum cover (Fig. 2a).

\section{Phenology}

Plants were fertile from the first sampling date and only a single sterile individual was found on 16 May. The number of forming individuals was high until 13 June (Fig. 2b). The number of fertilized individuals was highest on 7 June (Fig. 2b). Spore release started on 20 June and was high until the last sampling date (Fig. 2b). Individuals found later showed clear degradation of the reproductive structures.

\section{Variation in biochemical contents}

Total $\mathrm{N}$ and total $\mathrm{C}$ contents followed a parallel trend with higher values from 30 May to 3 July (Fig. 

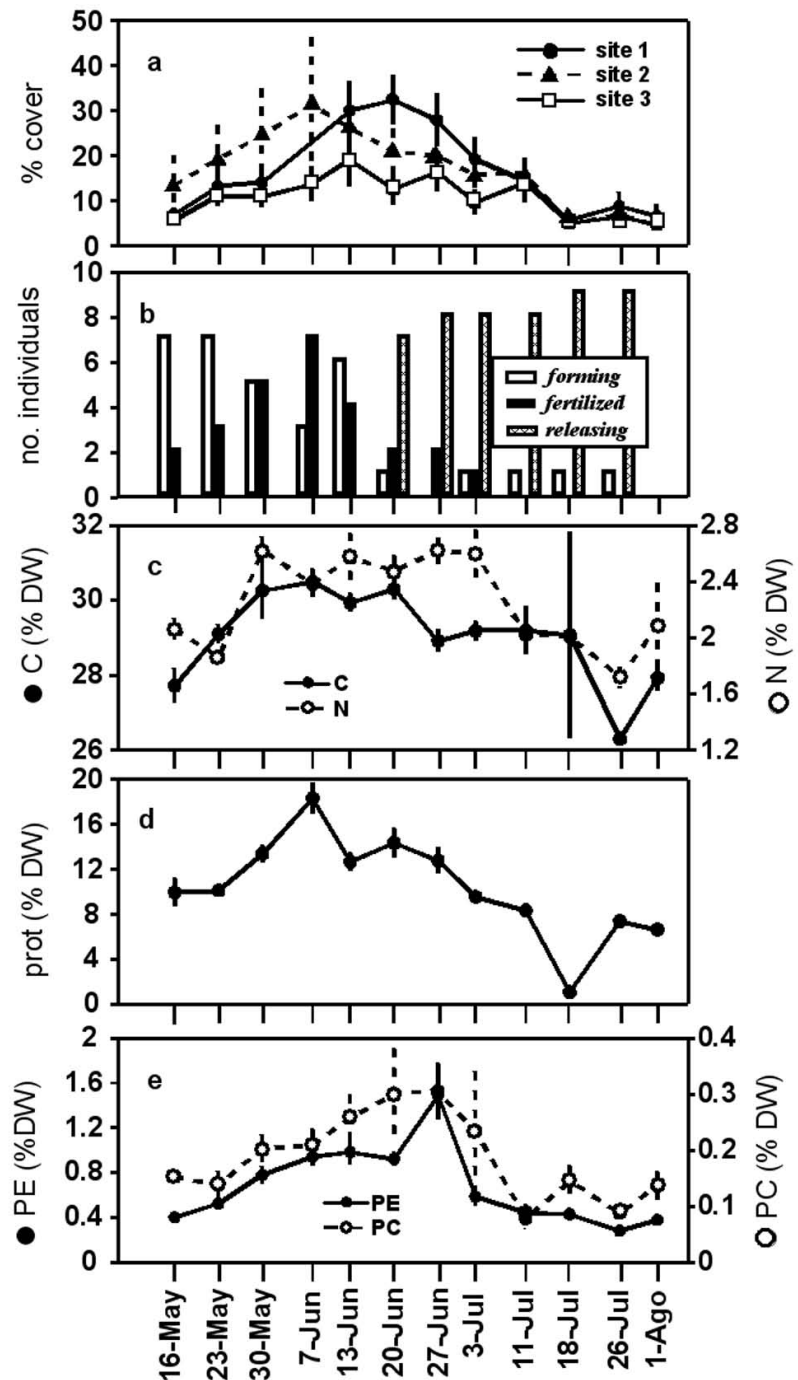

FIG. 2. - Variation in cover and proxies for physiological condition. a) Percentage cover for the three sampling zones (site $1, n=4$; site $2, \mathrm{n}=5$; site $3, \mathrm{n}=5$ ); b) Number of individuals forming gametes, showing fertilization and releasing spores $(n=10)$; c) $C$ and $N$ internal contents $(\mathrm{n}=4$, except $*$ in which $\mathrm{n}$ equals 2$)$; d) Total protein content $(n=8)$; e) Phycoerythrin and phycocyanin content $(n=8)$. Bars denote SE.

2c). The maximum protein content $(18.36 \pm 1.43 \% \mathrm{DW}$; mean \pm SE; $n=8$ ) was found on 7 June. Phycoerythrin content showed a delayed peak $(1.49 \pm 0.22 \% \mathrm{DW}$; mean \pm SE; $\mathrm{n}=8$ ) on 27 June, as did phycocyanin content $(0.30 \pm 0.05 \%$ DW; mean \pm SE; n=8) (Fig. 2d).

\section{Nutrient availability and environmental variation}

Nitrate + nitrite and phosphate values (Fig. 3a, b) were low when compared with usual autumn/winter values in this area (up to $7 \mu \mathrm{M}$ nitrate + nitrite and $0.3 \mu \mathrm{M}$ orthophosphate reported in Martínez and Rico, 2002). There was a trend for nitrate + nitrite (and occasionally for phosphate) to be lower at the third sampling site, which was located far from the freshwater stream, particularly on days with high nutrient levels (Fig. 3a,
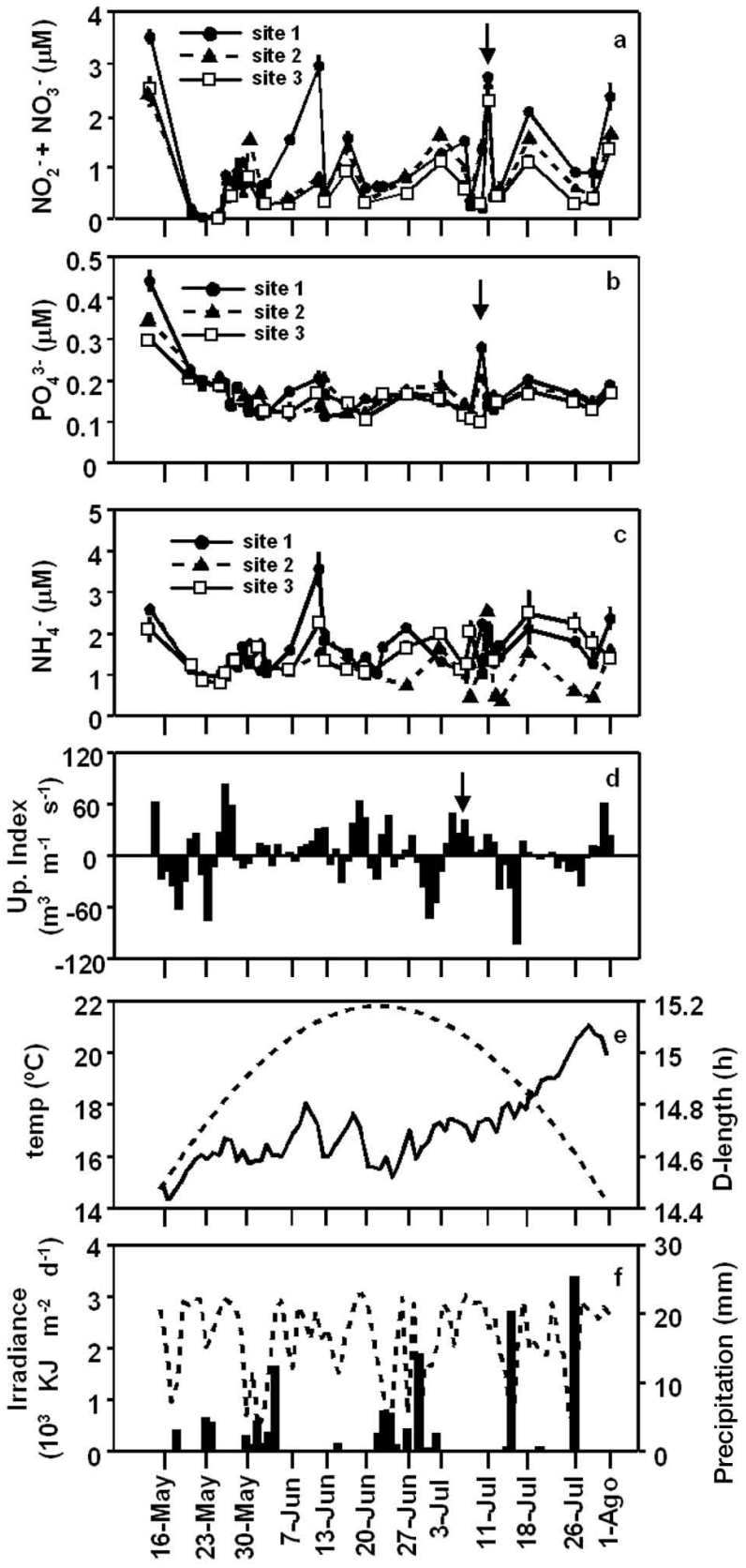

FIG. 3. - Variation in environmental variables. a-c) Nitrate+nitrite, phosphate and ammonium concentrations for the three sampling sites. Arrows represent an upwelling event $(n=3)$. Bars denote $\mathrm{SE}$; d) Upwelling index. Arrow represents an upwelling event; e) Seawater temperature and theoretical daylength; f) Daily integrated irradiance and precipitation.

b). Maximum values found on the first sampling date agreed with values found at the same site on the same date the following year (on 18 may 2004: nitrate + nitrite $=3.81 \pm 0.25 \mu \mathrm{M}$; phosphate $=0.24 \pm 0.008 \mu \mathrm{M}$; mean $\pm S E ; n=2$ ). These values were consistent with typical spring values in this area found before the late-spring thermocline is formed. More than $1 \mu \mathrm{M}$ of ammonium was found throughout the monitoring period and there was no trend among sites or dates (Fig. 3c). 
TABLE 2. - Percentage of variance explained by the factors selected for the reduced model (forward selection procedure, $\mathrm{p}<0.05$ ). Partial analyses give the amount of variability explained by each factor once the effect of the other has been removed. F test performed with Montecarlo iterative procedures.

\begin{tabular}{lccc}
\hline & $\begin{array}{c}\text { Total \% } \\
\text { explained variance }\end{array}$ & $\mathrm{F}$ & $\mathrm{p}$ \\
\hline RDA reduced model & 54.6 & 5.412 & 0.001 \\
partial of daylength & 28.4 & 5.628 & 0.001 \\
partial of temperature & 16.7 & 3.306 & 0.030 \\
\hline
\end{tabular}

On most of the days the Upwelling Index showed some positive values (Fig. 3d). However, only between 3 and 11 July (arrow on Fig. 3d) were persistent positive values found continuously over 9 consecutive days. This period was preceded and followed by periods of downwelling (Fig. 3d) and was associated with an increment in both nitrate + nitrite and phosphate concentrations (arrows in Fig. 3a, b). Seawater temperature showed increasing values towards the end of the summer (Fig. 3e). A theoretical daylength curve is shown in Fig. 3e; integrated irradiance did not show any trend throughout the cycle and low values were consistent with periods of rainfall (Fig. 3f).

\section{Relationship between variables measured in $N$. helminthoides and environmental variables}

The first two axes of the PCA explained $80.6 \%$ of the total variability of the response matrix (Table 1). After constraining the response data to the set of environmental variables the percentage of explained variance only dropped by $12.3 \%$, which indicated that no relevant environmental factors had been overlooked. When the full set of environmental variables was considered, only the first axis of the ordination was significant (Table 1). The forward selection procedure selected daylength $(F=6.11, p=0.005)$ and seawater temperature $(F=3.31, p=0.017)$ as the only significant explanatory variables. Daylength explained a larger amount of variance than temperature (Table 2). Only 9.3\% of the total variance (difference between the sum of the variance explained by the two partials and the total variance explained by the reduced model) was shared by daylength and temperature, which shows that these two variables are not correlated at this temporal scale (Lepš and Šmilauer, 2003).

TABLE 1. - Percentage of variance explained by the first two axes and by the total extracted axes in the PCA and RDA. The latter considers the full environmental data set. $F$ test performed with Montecarlo iterative procedures.

\begin{tabular}{lccc}
\hline \multirow{3}{*}{ Analysis } & \multicolumn{3}{c}{ \% explained variance } \\
\hline PCA & axis & $2^{\text {nd }}$ axis & Total \\
RDA full analysis & 57.5 & 23.1 & 100 \\
& 55.3 & $21.8^{\mathrm{a}}$ & 87.7 \\
& $F=3.707$, & $F=1.369$, & $F=2.670$, \\
& $p=0.001$ & $p=0.349$ & $p=0.058$ \\
\hline
\end{tabular}

a once the effect of the first axis has been taken off.

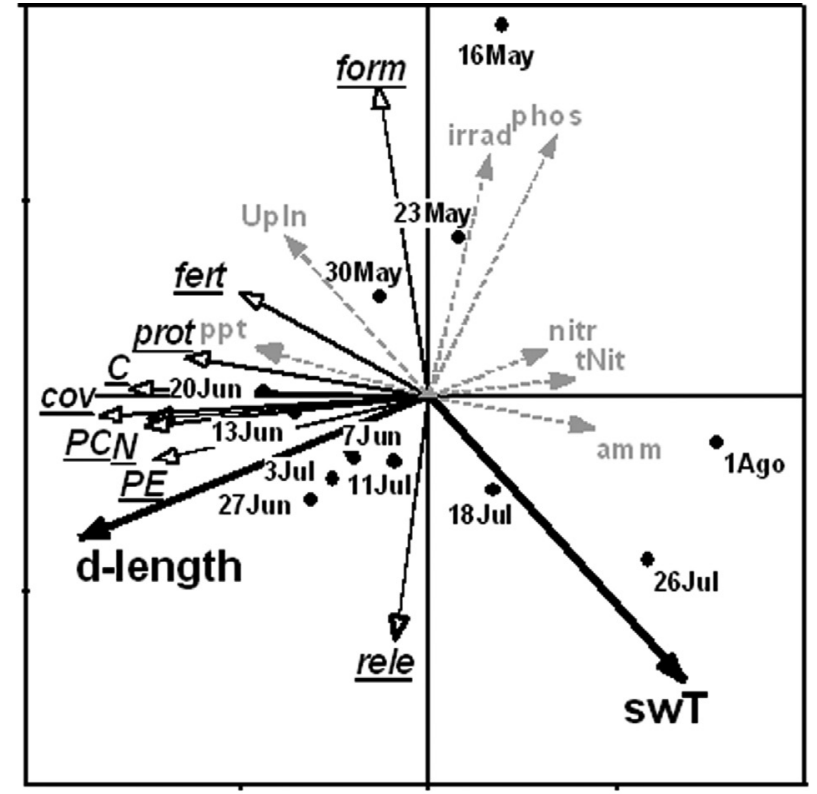

FIG. 4. - Reduced RDA plot. Samples were denoted with full circles with the corresponding date label. Response variables were represented with empty-headed arrows. Environmental variables included in the reduced model were signed out with thick full-headed arrows. Environmental variables excluded from the reduced model were added as supplementary and were represented by dashedhalftone arrows. Environmental variables: d-length, daylength; $s w T$, seawater temperature; irrad, integrated irradiance; UpIn, upllewing Index; ppt, precipitation; phos, seawater phosphate concentration; nitr, seawater nitrite+nitrate concentration, amm, seawater ammonium concentration, $t$ Nit, total seawater inorganic N. Response variables: cov, percentage cover; form, no. individuals forming gametes; fert, no. fertilized individuals, rele, no. individuals releasing spores; $C$, total internal $\mathrm{C} ; N$, total internal $\mathrm{N}$; prot, total protein content; $P E$, phycoerythrin; $P C$, phycocyanin.

The reduced model is shown in Figure 4. The samples were ordered in an anti-clockwise direction. The first axis was a linear combination of daylength and temperature, in which daylength was the major factor. Variations in percentage cover and internal biochemical contents were highest along this axis, which indicates that they were mainly related to variations in daylength. The arrows that represented these variables appeared above the arrow that represented daylength, showing that their maximum values were reached earlier than the maximum daylength value, and therefore under increasing daylength. The arrow that represented temperature pointed to samples taken later in the cycle, these samples showed low internal biochemical contents and advanced reproductive status. The only response variable positively correlated with temperature was the number of individuals releasing spores. Variables related to short-term nutrient supply such as nutrient seawater availability, Upwelling Index and precipitation were not significant in explaining variability in physiological condition. In fact, arrows that represented $\mathrm{N}$ availability in seawater were plotted in the opposite direction to samples with high $\mathrm{N}$ internal contents, which shows the total absence of a relationship (they were added to the plot as supplementary, with no effect on the ordination). 


\section{DISCUSSION}

With regard to the main hypothesis, no changes in the nutritional status of Nemalion helminthoides were detected as a response to the occurrence of transient nutrient inputs. As we expected, baseline nutrient levels in seawater remained low throughout the monitoring period but transient nutrient peaks in the intertidal fringe were detected. However, N. helminthoides did not show any physiological improvement when these peaks occurred (in terms of internal nutrient content, protein pools and phycobilins), although it grew and sporulated successfully during the summer, which suggests that it did actually benefit from these pulses. As reported for several macroalgae species growing under transient nutrient pulses (McGlathery, 1992; Barr and Rees, 2003; Costanzo et al., 2000; Nielsen, 2003), the nutrient requirements for sustaining maximum growth and high reproductive effort are usually higher than the mean nutrient availability, even in areas where nutrient background levels exceed those reported in this study (McGlathery, 1992; Pedersen and Borum, 1996, 1997; Phil et al., 1996; Fong et al., 1998; Barr and Rees, 2003; Nielsen, 2003). This nutrient restriction implies that the nutrient uptake during pulses is directly diverted into growth and reproduction (Fong et al., 1994; Vergara et al., 1995), which might explain the lack of short-term physiological responses in $N$. helminthoides.

The freshwater stream was the most consistent nutrient input during the sampling period. The sites next to the runoff showed a trend of higher nitrate + nitrite concentrations. In fact, samples taken in the stream during the following year showed nitrate values that usually exceeded $30 \mu \mathrm{M}$ (May to August in 2004, $40.13 \pm 3.20 \mu \mathrm{M} ;$ mean \pm SE; $\mathrm{n}=14)$. Accordingly, $N$. helminthoides plants located within the sampling areas closest to the freshwater runoff were longer than plants located further away (pers. obs.) where the lowest cover was measured. The stream supplies an additional transient nutrient input that seemed to alleviate nutrient limitation nearby.

The nitrate concentration showed an increment in early July that was associated with a period of upwelling conditions. However, this input took place when plants had already begun the process of senescence synchronized with the daylength becoming shorter and the temperature increasing (discussed below). Moreover, upwelling events registered in this area have not been shown to have any short-term effects on the physiological condition of the perennial red seaweeds Gelidium latifolium (Rico and Fernández, 1996) and Palmaria palmata (Martínez and Rico, 2008). This could be partially attributed to the presence of internal winter storage pools (although already low in summer); however, as the authors in the two previous references suggested, it is also possible that the intermittent occurrence of the upwellings stops the macroalgae from making a significant physiological response in the mid-Cantabrian Sea. Direct responses to rainfall were not evident, which suggests they have little effect on $N$. helminthoides nutrition.

The endogenous nature of the $N$. helminthoides cycle described by Cunningham and Guiry (1989) was also apparent in the field population studied. These authors found that the formation of the erect phase of $N$. helminthoides was determined by a strict combination of daylength and temperature (more than $14 \mathrm{~h}$ of light and less than $17^{\circ} \mathrm{C}$ ). In the field, ambient variations of daylength and temperature caused the variations in percentage cover, physiological condition and reproductive phenology of $N$. helminthoides. Daylength was the most important environmental factor for the synchronization of these three life-history elements.

In particular, the increment in the number of daylight hours promoted growth with a concomitant increment in $\mathrm{N}$ and $\mathrm{C}$ internal contents, and $\mathrm{N}$ pools. Proteins remained high during this period and allocated up to $93.66 \pm 5.1 \%$ of the total $\mathrm{N}$ internal content (from 16 May to 7 June; mean \pm SE; $n=31$; conversions as in Naldi and Wheeler, 1999), which suggests that most of them played a structural role, i.e. extracted with SDS. Phycobilins comprised a significant fraction of the total protein content $(10.63 \pm 1.44 \%$; mean $\pm S E ; n=87)$, and were closely correlated with daylength, which suggests that they play an important role as accessory photosynthetic pigments and $\mathrm{N}$ sinks in growing red seaweeds (Lobban and Harrison, 1997; Martínez and Rico, 2002, 2008). No net growth was observed when the days became shorter, and a general deterioration of the physiological condition occurred. Maturation of both male and female gametes and fertilization of female gametes occurred during the first 4 weeks of the cycle when the number of light hours was increasing, whereas maturation and release of spores took place in decreasing daylength. Therefore, the maximum percentage cover, better physiological performance, and peak in reproductive effort occurred at the same time.

The strength of the relationship between vegetative growth and reproductive effort in red seaweeds has been convincingly demonstrated by Kamiya and $\mathrm{Ka}-$ wai (2002) in three ceramiacean algae (Rhodophyta). In these species the number and size of spores released depended on the length of the vegetative branch on which carposporangia were being produced. This kind of relationship is also found in ephemeral shortlived seaweeds, in which there is no differentiation of thallus areas for reproduction and the reproductive output (gametes) usually occurs by degradation of the tissues (e.g. Pedersen and Borum, 1996; Schoschina, 1996; Clifton and Clifton, 1999). Similarly, in N. helminthoides, as in other Nemaliales, spores are released by leakage of the thalli (Dixon and Irvine, 1977; Hall and Murray, 1998; Sánchez et al., 2003) and is therefore linked with the decrease in net growth, the deterioration of the physiological condition, and finally, the senescence and disappearance of the plants from the field at the end of the cycle. During this time, the ambient temperature increased progressively. Actually, 
increases in temperature have been demonstrated to be a relevant factor in the rate of spore release in some red macroalgae (Guzmán-Urióstegui and Robledo, 1999; Garza-Sánchez et al., 2000). Our data suggest a similar response in $N$. helminthoides.

The direct relationship between $\mathrm{N}$ assimilation and $\mathrm{C}$ fixation is well known in photosynthetic organisms when they are actively growing. In these cases, the metabolic pathways that lead to the synthesis of proteins (GS-GOGAT and TCA-cycles) are predominant (reviewed in Huppe and Turpin, 1994). The parallel variation of $\mathrm{N}$ and $\mathrm{C}$ internal contents was also found by Hernández et al. (1993) in the winter-annual red seaweed Porphyra umbilicalis during the growing period. We found temporal coincidence between the decrease in $\mathrm{N}$ and $\mathrm{C}$ contents and the progressively decreasing daylength and increasing temperature, pointing to endogenous promoted senescence.

Most research on macroalgal ecophysiology deals with perennial harvestable seaweeds in which the period when there is a direct relationship between $\mathrm{N}$ and $\mathrm{C}$ generally goes unnoticed when it is considered within the inverse pattern between $\mathrm{N}$ and $\mathrm{C}$ contents (the so-called "Neish effect"), which is predominant most of the year (Neish et al., 1977; Juanes and McLachlan, 1992; Wheeler and Björnsäter, 1992; Chopin et al., 1995; Rico and Fernández, 1996; Martínez and Rico, 2002, 2008). The brief period during which $N$. helminthoides is present in the field makes this direct relationship evident. Field surveys of species with peculiar life-cycles, like the one reported in this study, are important for determining how the environment influences macroalgal development.

\section{ACKNOWLEDGMENTS}

B.M. thanks the financial support of the Ministry of Science and Technology of Spain (Projects CGL2007-66095/BOS, CGL2008-05407C03-01) and the Fundação para a Ciência e a Tecnologia of Portugal (project PTDC/MAR/105147/2008).

\section{REFERENCES}

Arrontes, J. - 1993. Nature of the distributional boundary of Fucus serratus on the north shore of Spain. Mar. Ecol. Prog. Ser., 93: 183-193.

Bakum, A. - 1973. Coastal upwelling indices, west coast North America, 1946-71. Seattle, Washington.

Barr, N.G. and T.A.V. Rees. - 2003. Nitrogen status and metabolism in the green seaweed Enteromorpha intestinalis: an examination of three natural populations. Mar. Ecol. Prog. Ser., 249: 133-144.

Beer, S. and A. Eshel. - 1985. Determining phycoerythrin and phycocyanin concentrations in aqueous crude extracts of red algae. Aust. J. Mar. Freshw. Res., 36: 785-792.

Blanchette, C.A. - 1996. Seasonal pattern of disturbance influence recruitment sea palm Postelsia palmaeformis. J. Exp. Mar. Biol. Ecol., 197: 1-14.

Botas, J.A., E. Fernández, A. Bode and R. Anadón. - 1990. A persistent upwelling of the central Cantabrian Coast (Bay of Biscay). Estuar. Coast. Shelf Sci., 30: 185-199.

Bracken, M.E.S. - 2004. Invertebrate-mediates nutrient loading increases growth of an intertidal macroalga. J. Phycol., 40:
1032-1041.

Breeman, A.M. and M.D. Guiry. - 1989. Tidal influences on the photoperiodic induction of tetrasporogenesis in Bonnemaisonia hamifera (Rhodophyta). Mar. Biol., 102: 5-14.

Chopin, T., T. Gallant and I. Davison. - 1995. Phosphorous and nitrogen nutrition in Chondrus crispus (Rhodophyta): effects on total phosphorous and nitrogen content, carrageenan production, and photosynthetic pigments and metabolism. J. Phycol., 31: $283-293$

Clavier, J., G. Boucher, L. Chauvaud, R. Fichez and S. Chifflet. -2005 . Benthic response to ammonium pulses in a tropical lagoon: implications for coastal environmental processes. J. Exp. Mar. Biol. Ecol., 316: 231-241.

Clifton, K.E. and L.M. Clifton. - 1999. The phenology and sexual reproduction by green algae (Bryopsidales) on Caribbean Coral reefs. J. Phycol., 35: 24-34.

Costanzo, S.D., M.J. O'Donohue and W.C. Dennison. - 2000. Gracilaria edulis (Rhodophyta) as a biological indicator of pulsed nutrients in oligotrophic waters. J. Phycol., 36: 680-685.

Cunningham, E.M. and M.D. Guiry. - 1989. A circadian rhythm in the long-day photoperiodic induction of erect axis development in the marine red alga Nemalion helminthoides. J. Phycol., 25: 705-712.

Dayton, P.K., M.J. Tenger, P.E. Parnell and P.B. Edwards. - 1992. Temporal and spatial patterns of disturbance and recovery in a kelp forest community. Ecol. Monogr., 62: 421-445.

Dixon, P.S. and L.M. Irvine. - 1977. Seaweeds of the British Isles. British Museum (Natural History), London.

Duarte, C.M. - 1992. Nutrient concentration of aquatic plants: patterns across species. Limnol. Oceanogr., 37: 882-889.

Edwards, M.S. - 2000. The role of alternate life-history stages of a marine macroalga: a seed bank analogue? Ecology, 81: 2404-2415.

Fong, P., R.M. Donohoe and J.B. Zedler. - 1994. Nutrient concentration in tissue of the macroalga Enteromorpha as a function of nutrient history: an experimental evaluation using field microcosms. Mar. Ecol. Prog. Ser., 106: 273-281.

Fong, P., K.E. Boyer and J.B. Zedler. - 1998. Developing an indicator of nutrient enrichment in coastal estuaries and lagoons using tissue nitrogen content of the opportunistic alga Enteromorpha intestinalis (L. Link). J. Exp. Mar. Biol. Ecol., 231: 63-79.

Fujita, R.D., P.A. Wheeler and R.L. Edwards. - 1989. Assessment of macroalgal nitrogen limitation in a seasonal upwelling region. Mar. Ecol. Prog. Ser., 53: 293-303.

Garza-Sánchez, F., J.A. Zertuche-González and D.J. Chapman. 2000. Effect of temperature and irradiance on the release, attachment and survival of spores of Gracilaria pacifica Abbott (Rhodophyta). Bot. Mar., 43: 205-212.

González, N., R. Anadón and L. Viesca. - 2003. Carbon flux through the microbial community in a temperate sea during summer: role of bacterial metabolism. Aquat. Microb. Ecol., 33: $117-126$.

Grasshoff, K., M. Ehrhardt and K. Kremling. - 1983. Methods of seawater analysis. Verlag Chemie, Weinheim, Germany.

Guiry, M.D. and C.J. Dawes. - 1992. Daylength, temperature and nutrient control of tetrasporogenesis in Asparagopsis armata. J. Exp. Mar. Biol. Ecol., 158: 197-217.

Guzmán-Urióstegui, A. and D. Robledo. - 1999. Factors affecting sporulation of Gracilaria cornea (Gracilariales, Rhodophyta) carposporophytes from Yucatan, Mexico. Hydrobiologia, 398/9: 285-290.

Hall, J.D. and S.N. Murray. - 1998. The life history of a Santa Catalina Island population of Liagora californica (Nemaliales, Rhodophyta) in the field and in laboratory culture. Phycologia, 37: 184-194.

Hernández, I., A. Corzo, F.J. Gordillo, M.D. Robles, E. Sáez, J.A. Fernández and F.X. Niell. - 1993. Seasonal cycle of the gametophytic form of Porphyra umbilicalis: nitrogen and carbon. Mar. Ecol. Prog. Ser., 99: 301-311.

Huppe, H.C. and D.H. Turpin. - 1994. Integration of carbon and nitrogen metabolism in plant and algal cells. Ann. Rev. Plant Physiol. Plant Mol. Biol., 45: 577-607.

Hwang, R.L., C.C. Tsai and T.M. Lee. - 2004. Assessment of temperature and nutrient limitation on seasonal dynamics among species of Sargassum from a coral reef, in southern Taiwan. $J$. Phycol., 40: 463-473.

Juanes, J.A. and J.L. McLachlan. - 1992. Productivity of Chondrus 
crispus Stackhouse (Rhodophyta, Gigartinales) in sublittoral Prince Edwards Island, Canada. II. Influence of temperature and nitrogen reserves. Bot. Mar., 35: 399-405.

Kamiya, M. and H. Kawai. - 2002. Dependence of the carposporophyte on the maternal gametophyte in three ceramiacean algae (Rhodophyta), with respect to carposporophyte development, spore production and germination success. Phycologia, 41: 107-115.

Kinlan, B.P., M.H. Graham, E. Sala and P.K. Dayton. - 2003. Arrested development of giant kelp (Macrocystis pyrifera, Phaeophyceae) embryonic sporophytes: a mechanism for delayed recruitment in perennial kelps? J. Phycol., 39: 47-57.

Kirk, J.T.O. - 1983. Light and photosynthesis in aquatic ecosystems. Cambridge Univ. Press, Cambridge.

Lartigue, J. and T.D. Sherman. - 2005. Response of Enteromorpha $s p$. (Chlorophyceae) to a nitrate pulse:nitrate uptake, inorganic nitrogen storage and nitrate reductase activity. Mar. Ecol. Prog. Ser., 292: 147-157.

Lepš, J. and P. Šmilauer. - 2003. Multivariate analysis of ecological data using CANOCO. Cambridge Univ. Press, Cambridge.

Lobban, C.S. and P.J. Harrison. - 1997. Seaweed Ecology and Physiology. Cambridge Univ. Press, Cambridge.

Lowry, O.H., N.J. Rosebrough, A.L. Farr and R.J. Randall. - 1951. Protein measurement with the folin phenol reagent. J. Biol. Chem., 193: 265-275.

Lubchenco, J. and J. Cubit. - 1980. Heteromorphic life histories of certain marine algae as adaptations to variations in herbivory. Ecology, 61: 676-687.

Lüning, K. - 1993. Environmental and internal control of seasonal growth in seaweeds. Hydrobiologia, 260/261: 1-14.

Martin, M.T. - 1969. A review of the life-histories in the nemalionales and some allied genera. Br. Phycol. J., 4: 145-158.

Martínez, B. and J.M. Rico. - 2002. Seasonal variation of P content and major N pools in Palmaria palmata (Rhodophyta). J. Phycol., 38: 1082-1089.

Martínez, B. and J.M. Rico. - 2008. Changes in nutrient content of Palmaria palmata in response to variable light and upwelling in northern Spain. J. Phycol., 44: 50-59.

McGlathery, K.J. - 1992. Physiological controls on the distribution of the macroalga Spyridea hypnoides: patterns along a eutrophication gradient in Bermuda. Mar. Ecol. Prog. Ser., 87: 173-182.

McGlathery, K.J. - 1996. Changes in intracellular nitrogen pools and feedback controls on nitrogen uptake in Chaetomorpha linum (Chlorophyta). J. Phycol., 32: 393-401.

Naldi, M. and P.A. Wheeler. - 1999. Changes in nitrogen pools in Ulva fenestrata (Chlorophyta) and Gracilaria pacifica (Rhodophyta) under nitrate and ammonium enrichment. J. Phycol., 35: 70-77.

Neish, A.C., P.F. Shacklock, C.H. Fox and F.J. Simpson. - 1977. The cultivation of Chondrus crispus. Factors affecting growth under greenhouse conditions. Can. J. Bot., 55: 2263-2271.

Nielsen, K.J. - 2003. Nutrient loading and consumers: agents of change in open-coast macrophyte assemblages. Proc. Natl. Acad. Sci. U. S. A., 100: 7660-7665.

O'Riordan, R.M., F. Arenas, J. Arrontes, J.J. Castro and T. Cruz. 2004. Spatial variation in the recruitment of the intertidal barnacles Chthamalus montagui Southwart and Chthamalus stellatus (Poli) (Crustacea: Cirripedia) over an European scale. J. Exp.
Mar. Biol. Ecol., 304: 243-264.

Palmer, M.W. - 1993. Putting things in even better order: the advantages of Canonical Correspondence Analysis. Ecology, 74: 2215-2230.

Pedersen, M.F. and J. Borum. - 1996. Nutrient control of alga growth in estuarine waters. Nutrient limitation and the importance of nitrogen requirements and nitrogen storage among phytoplankton and species of macroalgae. Mar. Ecol. Prog. Ser., 142: 261-272.

Pedersen, M.F. and J. Borum. - 1997. Nutrient control of estuarine macroalgae: growth strategy and the balance between nitrogen requirements and uptake. Mar. Ecol. Prog. Ser., 161: 155-163.

Pedersen, A., G. Kraemer and C. Yarish. - 2004. The effects of temperature and nutrient concentrations on nitrate and phosphate uptake in different species of Porphyra from Long Island Sound (USA). J. Exp. Mar. Biol. Ecol., 312: 235-252.

Phil, P., G. Magnusson, I. Isaksson and I. Wallentinus, I. - 1996. Distribution and growth dynamics of ephemeral macroalgae in shallow bays on the Swedish west coast. J. Sea. Res., 35: $169-180$.

Pueschel , C.M. and R.E. Korb. - 2001. Storage of nitrogen in the form of protein bodies in the kelp Laminaria solidungula. Mar. Ecol. Prog. Ser., 218: 107-114.

Reed, D.C., A.W. Ebeling, T.W. Anderson and M. Anghera. - 1996. Differential reproductive responses to fluctuating resources in two seaweeds with different reproductive strategies. Ecology, 77: 300-316.

Rico, J.M. and C. Fernández. - 1996. Seasonal nitrogen metabolism in an intertidal population of Gelidium latifolium (Gelidiaceae, Rhodophyta). Eur. J. Phycol., 31: 149-155.

Sánchez, I. and C. Fernández. - 2006. Resource availability and invasibility in an intertidal macroalgal assemblage. Mar. Ecol. Prog. Ser., 313: 85-94.

Sánchez, I., C. Fernández and J.M. Rico. - 2003. Distribution, abundance and phenology of two species of Liagora (Nemaliales, Rhodophyta) in northern Spain. Phycologia, 42: 7-17.

Schoschina, E.V., N.V. Makarov, G.M. Voskoboinikov and C. van der Hoek. - 1996. Growth and reproductive phenology of nine intertidal algae on the Murman coast of the Barents Sea. Bot. Mar., 39: 83-93.

ter Braak, C.J.F. - 1999. Ordination. In: R.H.G. Jongman, C.J.F. ter Braak, and O.F.R. van Tongeren (eds.), Data Analysis in Community and Landscape Ecology, pp. 91-173. Cambridge Univ. Press, Cambridge, UK.

Valiela, I. - 1995. Marine Ecological Processes. Springer, New York.

Vergara, J.J., K.T. Bird and F.X. Niell. - 1995. Nitrogen assimilation following $\mathrm{NH}_{4}{ }^{+}$pulses in the red alga Graciliaropsis lemaneiformis: effect on C metabolism. Mar. Ecol. Prog. Ser., 122: 253-263.

Wheeler, P.A and B.R. Björnsäter. - 1992. Seasonal fluctuations in tissue nitrogen, phosphorous, and N:P for five macroalgal species common to the Pacific northwest coast. J. Phycol., 28: 1-6.

Scient. ed.: E. Ballesteros.

Received December 11, 2009. Accepted September 10, 2010.

Published online March 8, 2011. 